\title{
Pengaruh Service Marketing Mix dan Customer Value Terhadap Kepuasan Mahasiswa Program Studi Manajemen Fakultas Ekonomi Universitas Maritim Raja Ali Haji
}

\author{
Iranita
}

Fakultas Ekonomi Universitas Maritim Raja Ali Haji, Tanjungpinang, Kepulauan Riau, Indonesia

\begin{abstract}
ABSTRAK: Objek penelitian diperoleh mengenai pengaruh Service Marketing Mix dan Customer Value terhadap kepuasan mahasiswa Program studi manajemen Fakultas Ekonomi UMRAH. Tipe dari penelitian adalah explanatory. Hasil hasil dari penelitian menunjukkan bahwa service marketing mix yang terdiri dari produk (product), harga (price), distribusi (place), promosi (promotion), orang (people), bukti langsung (physical evidence) dan proses (process, dan customer value meliputi Customer benefit dan customer cost baik secara parsial dan secara simultan berpengaruh erat terhadap kepuasan mahasiswa Program Studi Manajemen Fakultas Ekonomi UMRAH
\end{abstract}

Keywords: Service Marketing Mix, Customer Value, Kepuasan Mahasiswa

ABSTRACT: The object of the study was obtained about the effect of Service Marketing Mix and Customer Value on student satisfaction in the UMRAH Faculty of Economics management study program. The type of research is explanatory. The results of the study indicate that the service marketing mix consists of products (product), price (price), distribution (place), promotion (people), people (people), direct evidence (physical evidence) and process (process, and customer value includes Customer benefit and customer cost both partially and simultaneously has a strong influence on student satisfaction in the UMRAH Faculty of Economics Management Study Program

Keywords: Service Marketing Mix, Customer Value, Student Satisfaction

Email Address : iranita27@gmail.com / iranita@umrah.ac.id 


\section{Pendahuluan}

Pendidikan merupakan faktor penting bagi kelangsungan kehidupan bangsa dan faktor pendukung yang memegang peranan penting di seluruh sektor kehidupan. Pembangunan pendidikan merupakan salah satu prioritas utama dalam agenda pembangunan nasional. Pembangunan pendidikan sangat penting karena perannya yang signifikan dalam mencapai kemajuan di berbagai bidang kehidupan :sosial, ekonomi, politik dan budaya.

Oleh karena itu, pemerintah berkewajiban untuk memenuhi hak setiap warga Negara dalam memeperoleh layanan pendidikan guna meningkatkan kualitas hidup bangsa Indonesia sebagaimana diamantkan oleh UUD 1945, yang mewajibkan pemerintah bertanggungjawab dalam mencerdaskan kehidupan bangsa dan menciptakan kesejahteraan umum. Pendidikan menjadi landasan kuat yang diperlukan untuk meraih kemajuan bangsa pada era global yang sarat dengan persaingan antar bangsa yang berlangsung sangat ketat. Dengan demikian, pendidikan determinan bagi suatu bangsa untuk bias memenangi kompetisi global.

Universitas Maritim Raja Ali Haji (UMRAH) merupakan satu-satunya universitas negeri yang ada di Provinsi Kepulauan Riau, yang berfugsi menyelenggarakan pendidikan dan pengajaran, penelitian, dan pengabdian masyarakat, sesuai dengan TriDharma Perguruan Tinggi yang diembannya. UMRAH merupakan perguruan tinggi swasta mitra pemerintah dalam memajukan sektor pendidikan untuk menciptakan kualitas sumber daya manusiaIndonesia yang unggul, menjadi bangsa yang bermartabat, dan memiliki kedudukan sama dengan bangsabangsa lain di dunia. Saat ini di UMRAH. Saat ini di UMRAH memiliki 5 Fakultas, yaitu Fakultas Ekonomi (FE), Fakultas Ilmu

Kelautan dan Perikanan (FIKP), Fakultas Keguruan dan Ilmu Pendidikan (FKIP), Fakultas teknik (FT), Fakultas Sosial dan Politik (FSIP).

Program Studi Manajemen Fakultas Ekonomi UMRAH mulai beroperasi dengan SK 696/E.E2/DT/2013 tanggal 23 Juli 2013 dan telah terakreditasi dengan nilai C. Dalam 4 (empat) tahun terakhir ini Program studi Manajemen UMRAH mengalami trend peningkatanan atau bertambahnya jumlah mahasiswa. Hal ini dapat dilihat pada Tabel 1.1 berikut ini:

Tabel 1.1

Jumlah Mahasiswa Program Studi Manajemen Fakultas Ekonomi UMRAH TA. 2013 sampai 2017

\begin{tabular}{|c|c|}
\hline Tahun Akademik & Jumlah Mahasiswa \\
\hline $2013 / 2014$ & 19 \\
\hline $2014 / 2015$ & 101 \\
\hline $2015 / 2016$ & 58 \\
\hline $2016 / 2017$ & 111 \\
\hline & 289 \\
\hline
\end{tabular}

Sumber: Bag Akademik FE, 2017

Dari tabel di atas diketahui ada peningkatanan jumlah mahasiswa Program Studi Manajemen Fakultas Ekonomi UMRAH. Hal ini tidak terlepas dari strategi bauran pemasaran jasa yang telah diterapkan. Dalam memahami pemasaran jasa pendidikan tinggi, strategi yang diterapkan tidak terlepas dari bauran pemasaran. Strategi bauran pemasaran dalam hubungannya dengan pemasaran jasa Perguruan Tinggi meliputi produk (Program studi), harga (biaya pendidikan), promosi, lokasi, orang, proses dan bukti langsung.

Program Studi Manajemen UMRAH berupaya meningkatkan kualitas pelayanan seperti perbaikan fasilitas fisik gedung, 
peralatanan pendukung kegiatan pembelajaran, pemberdayaan dosen-dosen untuk melanjutkan pendidikan ke jenjang yang lebih tinggi. Selain kepuasan mahasiswa, melanjutkan pendidikan ke jenjang yang lebih tinggi. Selain itu kepuasan mahasiswa, peningkatan kualitas dan kinerja pendidikan dilakukan agar tetap mampu bersaing dengan berbagai perguruan tinggi lainnya yang semakin banyak.

UMRAH sebagai satu-satunya

Universitas Negeri di provinsi Kepulauan Riauyang menawarkan pendidikan tinggi dari berbagai disiplin keilmuan. Berbekal pengalaman selama sepuluh tahun, dan didukung oleh dosen dan pegawai berdedikasi tinggi, kepemimpinan yang kuat dengan komitmen yang teguh, serta kepercayaan masyarakat yang tinggi, UMRAH akan senantiasa berkomitmen dan memainkan peranan penting dalam menghasilkan lulusan berkualitas demi masa depan bangsa. Komitmen jangka panjang Universitas Raja Ali Haji sesuai dengan Visi dan Misi UMRAH.Saat ini sedang mengalami masalah intern yang dapat menganggu proses pembelajaran dan pemberian pelayanan kepada mahasiswa. Permasalahan ini cukup berpengaruh hampir di seluruh Fakultas di UMRAH, khususnya di Fakultas Ekonomi. Para pegawai (tendik)dan dosen dinilai tidak dapat memberikan pelayanan yang maksimal kepada mahasiswanya, akibat dari permasalahan peningkatnan jumlah mahasiswa yang tidak diikuti peningkatann kualitas pelayanan melalui peningkatanan kualitas sumber daya manusia yang ada di UMRAH. Hal ini tentunya akan berdampak pada minat calon mahasiswa baru untuk masuk ke UMRAH. Kemudian masih terdapat pegawai yang sering meninggalkan pekerjaannya, sehingga pelaksanaan administrative yang seharusnya dilakukan menjadi terkendala. Bahkan sering terdapat pekerjaan yang tertunda-tunda yang menyebabkan pegawai yang mengerjakan pekerjaan tersebut tidak berada di ruang kerjanya masing-masing.

\section{PERUMUSAN MASALAH}

Dari latarbelakang yang telah di paparkan di atas, dapat dirumuskan permasalahan dalam penelitian ini yaitu:

1. Apakah service marketing mix berpengaruh terhadap kepuasan mahasiswa

2. Apakah customer value berpengaruh terhadap kepuasan mahasiswa

3. Apakah service marketing mix berpengaruh terhadap kepuasan mahasiswa

\section{Tujuan Penelitian}

1. Mengetahui pengaruh service marketing mix terhadap kepuasan mahasiswa

2. Mengetahui pengaruh customer value terhadap kepuasan mahasiswa

3. Mengetahui pengaruh service marketing mix terhadap kepuasan mahasiswa

\section{Kajian Pustaka \\ Pemasaran Jasa}

Pemasaran jasa adalah proses sosial dan manajerial dengan mana seseorang atau kelompok memperoleh apa yang mereka butuhkan dan inginkan melalui penciptaan dan pertukaran produk dan nilai (Kotler, 2005). Stanton (2004) mengemukakan bahwa pemasaran adalah suatu sistem keseluruhan dari kegiatan-kegiatan bisnis yang ditujukan untuk merencanakan, menentukan harga, mempromosikan, mendistribusikan barang dan jasa yang menawarkan kebutuhan baik kepada pembeli yang ada maupun pembeli potensial.

Jasa adalah fenomena yang rumit (complicated), kata jasa mempunyai banyak arti dan ruang lingkup, dari kata yang paling sederhana yaitu berupa pelayanan dari seseorang kepada orang lain. Jasa adalah setiap tindakan atau aktifitas dan bukan benda, 
yang dapat ditawarkan oleh suatu pihak kepada pihak lain, yang dasarnya bersifat intangible (tidak berwujud fisik), konsumen terlibat aktif dalam proses produksi dan tidak menghasilkan kepemilihan sesuatu.

Kotler (2005), menyatakan bahwa jasa adalah setiap tindakan atau kegiatan suatu pihak yang dapat ditawarkan kepada pihak lain yang secara esensial tidak berwujud dan tidak mengakibatkan kepemilikan sesuatu. Jasfar (2005) menyatakan bahwa jasa hanya berupa pelayanan dari seseorang kepada orang lain baik yang dapat dilihat (explicit service) atau yang tidak dapat, yang hanya bias dirasakan (implicit service) sampai kepada fasilitas-fasilitas pendukung yang harus tersedia dalam pernjualan jasa dan bendabenda lain.

\section{Bauran Pemasaran Jasa (Service Marketing} Mix)

Menurut Kotler (2005), Bauran pemasaran adalah seperangkat alat pemasaran yang digunakan pemasaran untuk mencapai tujuan pemasarannya dalam pasar sasaran.Bauran pemasaran tidak adanya batasnya terhadap jumlah variable-variabel pemasaran. Oleh karena itu tidak menuutp kemungkinan untuk berkembang dan meluas sesuai dengan kebutuhan perusahaan. Selanjutnya menurut Lupiyoadi (2011), bahwa sebagai suatu bauran pemasaran jasa, elemen tersebut (produk, harga promosi, tempat, orang proses, pelayanan) saling memepengaruhi satu sama lain sehingga bila salah satu tidak tepat mengorganisasiannya akan mempenagruhi startegi pemasaran secara keseluruhan.

Bauran pemasaran jasa sebagaimana dikemukakan di atas terdiri dari tujuh elemen yaitu produk (product), harga (price), distribusi (place), promosi (promotion), orang (people), bukti langsung (physical evidence) dan proses (process)

\section{Konsep Customer Value}

Nilai yang diterima pelanggan merupakan salah satu unsur penting yang perlu dipertimbangkan ketika proses perumusan konsep suatu produk. Hal tersebut sangat penting karena pelanggan saat ini menghadapi beraneka ragam pilihan produk, merk, harga dan pemasok, dan Kotler (2005:60) mendefinisikan nilai sebagai berikut:

"Total Customer Value is the bundle of benefit customers expect from a given product or service. Total Customer Cost is bundle of costs customer expect to incure in evaluating, obtaining, using the product or service and disposing of the product or service. Customer Delivered Value is difference between Total Customer value and Total customer Cost"

Nilai yang diterima pelanggan (Customer Delivery Value) adalah perbandingan antara jumlah total nilai bagi pelanggan (Total Customer Value) dengan biaya total pelanggan (Total Customer Cost). Jumlah nilai bagi pelanggan adalah kumpulan manfaat yang diharapkan diperoleh pelanggan dari produk/jasa tertentu. Biaya total pelanggan adalah kumpulan pengorbanan yang diperkirakan pelanggan akan terjadi dalam mengevaluasi, memperoleh dan menggunakan produk atau jasa tersebut.

Lovelock (2002:174) mendefinisikan Value sebagai "what I get for what I give" dan memperkenalkan konsep Net value dimana konsumen akan mempertimbangkan perbedaan antara benefit yang diterima dengan penngorbanan yang harus dikeluarkan. Semakin besar benefit yang diterima konsumen dibandingkan dengan pengorbanannya, maka semakin besar pula nilai yang diterima. Persepsi tentang benefit dan biaya mungkin saja bervariasi antara konsumen yang satu dengan konsumen lain. Nilai yang diterima konsumen juga bervariasi. Beberapa konsumen menghendaki produk dan sejumlah konsumen lain menghendaki kualitas. Demikian juga pengorbanan yang dikeluarkan, beberapa konsumen hanya 
berkepentingan dengan jumlah uang yang dikeluarkan. Kotler juga memformulasikan Customer Value sebagai rasio antara Perceived Benefit dan Cost, Secara singkat:

$$
V=\frac{B}{C}(\text { Kotler; } 2005: 60)
$$

$$
\text { Dimana: } \quad \begin{aligned}
\mathrm{V}= & \text { Customer Value } \\
\mathrm{B}=\text { Perceived Benefit } & \mathrm{C}=\text { Cost }
\end{aligned}
$$

Value juga merupakan ratio antara yang mendapatkan konsumen dengan apa yang dikorbankan konsumen, konsumen mendapat benefit dan mengorbankan cost. Semakin tinggi skor Customer Benefit maka menunjukkan semakin besar keuntungan yang bisa diberikan perusahaan kepada konsumen.Demikian sebaliknya semakin rendah skornya menunjukkan semakin banyak pengorbanan yang diberikan oleh konsumen, sedangkan semakin tinggi skor berarti semakin sedikit pengorbanan yang diberikan konsumen.

\section{Kepuasan Konsumen}

Untuk dapat mengetahui tingkat kepuasan konsumen secara lebih baik, maka perlu dipahami pula sebab-sebab kepuasan.Terciptanya kepuasan konsumen dapat memberikan beberapa manfaat, diantaranya hubungan antara perusahaan dan konsumennya menjadi harmonis. Ada beberapa pendapat para pakar tentang definisi kepuasan dan ketidakpuasan konsumen, diantaranya adalah:

Menurut Kotler (2005:36): "Customer satisfactions is a person's feeling of pleasure or disappointment resulting from

comparing a product's perceived performance (or outcome) in relation to his or her expectation." Sejalan dengan itu Freddy Rangkuti, (2002:56) mengatakan bahwa kepuasan atau ketidakpuasan pelanggan adalah respon konsumen terhadap evaluasi ketidakpuasan atau diskonfirmasi yang dirasakan antar harapan sebelumnya dengan kinerja aktual dari produk/jasa yang dirasakan pemakai.

Disamping itu Parasuraman, Zeithmal and Berry (1996) mendefinisikan bahwa

Customer Satisfaction: "customer satisfaction is customer perception of a single service experience." dimana persepsi konsumen terhadap satu jenis pelayanan yang dialaminya, hal ini berarti bahwa konsumen akan memiliki persepsi atau pendapat sendiri terhadap pelayanan yang diterimanya, apakah pelayanan tersebut memberikan kepuasan atau malah sebaliknya.

Hal yang sama diungkapkan oleh Kotler (2005) bahwa Customer Satisfactionadalah Variabel Perceived Quality perasaan senang atau kecewa seseorang yang berasal dari perbandingan antara kesannya terhadap kinerja atau hasil suatu produk dan harapan.

Disamping itu menurut Kotler (2005), suatu perusahaan dapat mengukur kepuasan pelanggannya dengan beberapa cara yakni : Pertama, sistem keluhan dan saran (complaint dan suggestion system). Kedua, survei kepuasan pelanggan (customer satisfaction survei). Ketiga, pembeli bayangan (ghostshopping). Keempat, analisis pelanggan yang hilang (loss customer analysis).

Lupiyoadi (2011) menjelaskan bahwa menentukan tingkat kepuasan konsumen dipengaruhi oleh lima faktor yaitu kualitas produk, kualitas layanan, faktor emosional, harga serta biaya dan kemudahan mendapatkan produk/jasa. Selanjutnya Yamit (2003) mengungkapkan bahwa kepuasan

pelanggan ditentukan oleh kualitas fenomena dalam pelayanan di lapangan. Apabila pelayanan (service) tidak sama atau tidak sesuai dengan harapan (expectation) 
pelanggan, maka dimata pelanggan, pelayanan yang diberikan dinilai jelek dan tidak memuaskan

\section{Pengukuran Kepuasan Konsumen}

Kepuasan konsumen merupakan fungsi dari kedekatan hubungan antara harapan konsumen (customer expectation) dengan kinerja produk yang dirasakan oleh konsumen (perceived performance), sehingga maka kepuasan konsumen menurut Sucherly (2004:18) dapat ditentukan dengan menggunakan rumus:

$$
=\frac{\text { PERCEIVED PERFORMANCE }}{\text { CUSTOMER EXPEXTATION }} \times 100 \%
$$

Pada dasarnya customer satisfaction tidak dapat dipenuhi seluruhnya karena itu perceived performance tidak dapat mencapai customer expectation. Selisihnya adalah ketidakpuasan (dissatisfaction) konsumen terhadap produk/jasa.

\section{Kerangka Pemikiran dan Hipotesis}

Setiap lembaga pendidikan untuk meningkatkan jumlah mahaasiswanya tidak terlepas dari strategi bauran pemasaran jasa. Bauran pemasaran jasa merupakan elemenelemen organisasi yang dapat dikontrol oleh organsasi dalam melakukan komunikasi dengan konsumen dan akan dipakai untuk memuaskan konsumen. Menurut Yazid (2003) bauran pemasaran terdiri dari semua variable yang bisadikontrol oleh perusahaan dalam komunikasinya dan dipakai untuk memuaskan konsumen sasaran. Bauran pemasaran jasa terdiri dari 7p's yaitu:produk (product), harga (price), distribusi (place), promosi (promotion), orang (people), bukti langsung (physical evidence) dan proses (process).
Menurut Payne (2001) bahwa produk jasa, harga ketersediaan jasa dan lokasi (tempat) jasa, promosi, orang, proses, layanan pelanggan dapat dimanfaatkan, untuk memuaskan konsumen, dalam hal ini calon mahasiswa Bauran Pemasaran berpengaruh terhadap kepuasan konsumen. Oleh karena itu bauran pemasaran adalah strategi yang digunakan

dalam bidang pemasaran untuk menciptakan pertukaran dalam mencapai tujuan perusahaan yaitu untuk memperoleh laba dan dapat meningktakan volume penjualan produknya, sehingga produk perusahaan tersebut akan meningkat apabila konsumen memutuskan untuk membeli produk tersebut (Widjaya, 2005). Dari uraian di atas maka, kerangka berfikir dari penelitian ini dapat digambarkan pada gambar berikut:

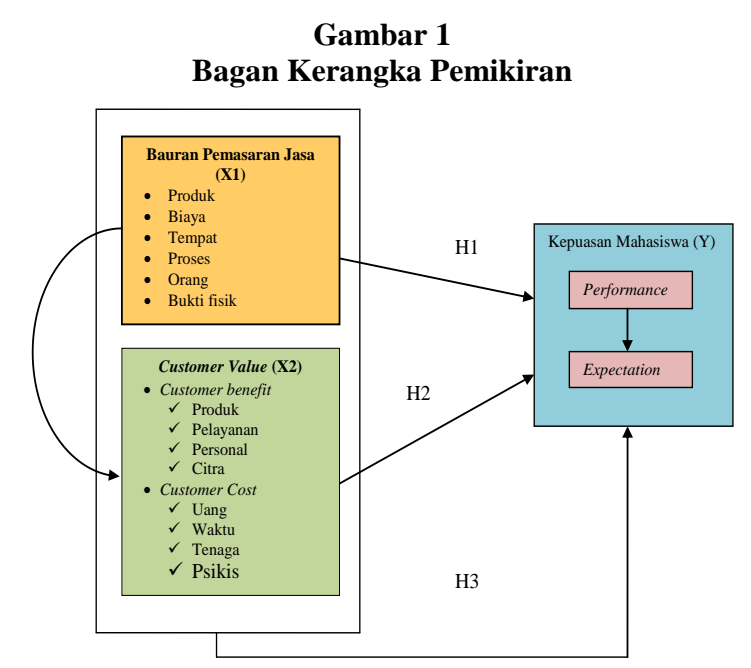

\section{Metode Penelitian}

Penelitian ini menggunakan pendekatan kuantitatif. Berdasarkan teknik pengumpulan data dan informasi, dalam penelitin ini menggunakan dua macam data, yaitu data primer dan data sekunder. Data primer diperoleh melalui survey (Singarimbun dan Effendi, 1991), dengan alasan keterbatasan waktu dan biaya, dan karakteristik responden sesuai dengan permasalahan penelitian (Malhotra, 2004). 
Pada penelitian ini, yang menjadi target populasi adalah mahasiswa Program Studi manajemen Fakultas Ekonomi UMRAHyang kuliah aktif. Keseluruhan populasi tidak mungkin diteliti karena keterbatasan biaya, waktu dan tenaga. Oleh karena itu pengambilan sampel dapat mewakili sebuah populasi (Cooper dan Schinder, 2006). Besarnya sampel menggunakan rumus Slovin (Umar, 2005) sebagai berikut:

$$
\mathrm{n}=\frac{N}{1+N e^{2}}=\frac{289}{1+289(0,10)^{2}}=74 \text { orang }
$$

Berdasarkan perhitungan di atas diperoleh jumlah sampel penelitian ini sebanyak 74 orang mahasiswa sebagai responden penelitian. Selanjutnya jumlah sampel ini ditentukan dengan random sampling. Teknik yang digunakan adalah cross section, sehingga tidak perlu ada uji kemaknaan (test of significan. Untuk memudahkan pengujian hipotesis digunakan perangkat lunak komputer berupa program Lisrel 8.5 dan Microsoft Excel versi 2007. Dari pengujian ini nantinya dapat dilihat seberapa besar kontribusi variabel bebas (Bauran Pemasaran Jasa, customer value) terhadap variabel terikatnya (kepuasan mahasiswa).

\section{Hasil Penelitian dan Pembahasan}

\section{Tanggapan Mahasiswa Terhadap Bauran Pemasaran Jasa}

Berdasarkan hasil penelitian dengan menyebarkan kuesioner pada mahasiswa program studi manajemen dan menggunakan indikator produk (product), harga (price), distribusi (place), promosi (promotion), orang (people), bukti langsung (physical evidence) dan proses (process) maka diperoleh bahwa sebagian besar tanggapan mahasiswa yang memberikan ketidakpuasan mahasiswa adalah berkenaan produk (product)yaitu akreditasi prodi. Indikator harga (price)yaitu berkenaan penetapan biaya membawa dampak pada kepuasan mahasiswa sesuai dengan Lupiyoadi (2011) bahwa keputusan penetapan harga juga penting.Untuk indikator tempat (place) berkenaan dengan letak kampus yang tidak dilalui oleh angkutan umum, jauh dari tempat kost, jauh dari tindakan kriminal. Indikator proses (process) berkenaan dengan prosedur pengurusan LIRS dan LIHS yang dilakukan dengan online, pengurusan surat menyurat. Indikator orang (people)berkenaan dengan dosen penasehat akademik (PA), pimpinan program studi manajemen, dan pegawai tata usaha Fakultas Ekonomi. Sedangkan untuk bukti fisik (physical evidence)berkenaan dengan ketersediaan kantin, kondisi gedung, kebersihan, kenyamanan, lapangan parkir, masjid, akses internet, media pembelajaran yang masih dirasa kurang.

\section{Tanggapan Mahasiswa Terhadap Customer Value}

Customer value yang diterima mahasiswa Program studi manajemen Fakultas Ekonomi UMRAH terhadap kepuasan mahasiswa terdiri dari dua subvariabel yaitu :customer benefit dan customer cost. Dari hasil penelitian diperoleh bahwa tanggapan mahasiswa terhadap costumer value yang di terima dalam memperoleh kepuasan sebagian besar menilai tinggi, meski ada sekitar $10 \%$ yang menganggap bahwa kemampuan Program studi dalam mengadakan sarana dan prasarana masih rendah. Hal ini terbukti karena di terimanya surat keberatan terhadap ketidaknyamanan dalam proses pembelajaran yang diterima oleh mahasiswa. Selain itu juga dengan kemampuan perusahaan dalam menyelesaikan masalah dan ketersediaan media pembelajaran yang dinilai masih rendah. Hal ini disebabkan dan diakui oleh Fakultas karena terbatas nya kemampuan Universitas dalam menlakukan pengadaan terhadap media pembelajaran dan rendahnya antisipasi dalam tindakan yang efektif 
Pengaruh Bauran Pemasaran Jasa Dan Customer Value Terhadap Kepuasan Mahasiswa Program Studi Manajemen Fakultas Ekonomi Universitas Maritim Raja Ali Haji

\section{(a) Pengujian Hipotesis Pertama}

Berdasarkan hasil perhitungan maka diperoleh besarnya pengaruh langsung dari kualitas $\left(\mathrm{X}_{1}\right)$ terhadap hasil penjualan $(\mathrm{Y})$ yaitu 0,4621 atau $46,21 \%$. Besarnya pengaruh tidak langsung dari bauran pemasaran jasa $\left(\mathrm{X}_{1}\right)$ melalui costumer value $\left(\mathrm{X}_{2}\right)$ terhadap kepausan mahasiswa (Y) adalah 0,2354 atau $23,54 \%$, sehingga di peroleh total pengaruh langsung dan tidak langsung dari bauran pemasaran jasa $\left(\mathrm{X}_{1}\right)$ terhadap kepuasan mahasiswa (Y)yaitu 0,4326 atau 43,26\%. Lebih jelasnya dapat di lihat pada Grafik berikut ini:

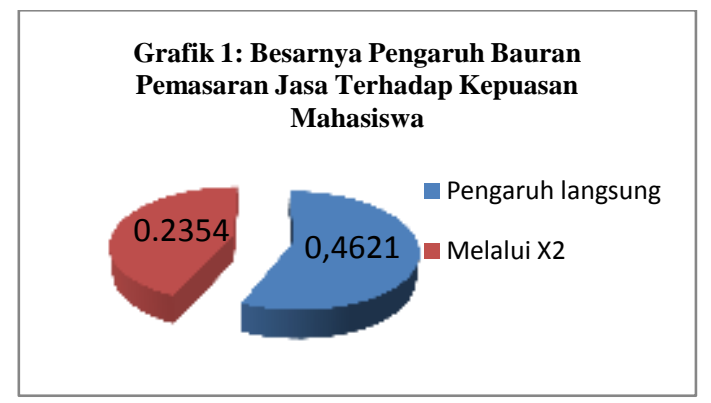

Sumber: dari data olahan tahun 2017

Interprestasi hipotesis penelitian yaitu hipotesis pertama menyatakan bauran pemasaran jasa $\left(\mathrm{X}_{1}\right)$ berpengaruh secara parsial terhadap kepuasan mahasiswa program studi Fakultas Ekonomi UMRAH (Y).Dalam hal ini hipotesis penelitian teruji artinya variabel kualitas $\left(\mathbf{X}_{1}\right)$ berpengaruh secara parsial terhadap kepuasan mahasiswa (Y).

\section{(b)Pengujian Hipotesis Kedua}

Berdasarkan hasil perhitungan maka di peroleh besarnya pengaruh langsung dari customer value (X2) terhadap kepuasan mahasiswa (Y) yaitu 0,4821 atau $48,21 \%$. Besarnya pengaruh tidak langsung dari custumer value (X2) melalui bauran pemasaran jasa (X1) terhadap kepuasan mahasiswa (Y) adalah 0,1881 atau 18,81\%, sehingga diperoleh total pengaruh langsung dan tidak langsung dari customer value (X2) terhadap kepuasan mahasiswa (Y) yaitu 0,4165 atau $41,65 \%$. lebih jelasnya dapat dilihat pada Tabel 4.51 dan Grafik 4.2 berikut ini :

Grafik 2: Besarnya Pengaruh Customer Value Terhadap Kepuasan Mahasiswa

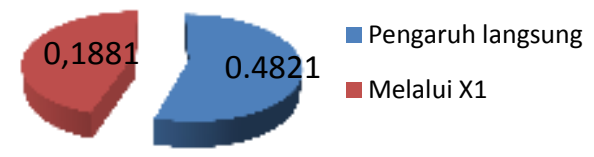

Sumber: dari data olahan tahun 2017

Interprestasi hipotesis penelitian yaitu hipotesis kedua menyatakan customer value $\left(\mathrm{X}_{2}\right)$ berpengaruh secara parsial kepuasan mahasiswa (Y),dalam hal ini hipotesis penelitian teruji artinya variabel customer value $\left(\mathrm{X}_{2}\right)$ berpengaruh secara parsial terhadap kepuasan mahasiswa $(\mathrm{Y})$.

\section{(c) Pengujian Hipotesis Ketiga}

Melalui hasil perhitungan matriks korelasi dan matriks invers korelasi antara variabel bebas (independenpen) maka diperoleh koefisien jalur atau besarnya pengaruh masing-masing variabel bebas (independen) $\mathrm{Xi}$ terhadap variable terikat (dependen)Y.Hasil perhitungan menunjukkan besarnya koefisien jalur bauran pemasaran jasa (X1) terhadap kepuasan mahasiswa (Y) adalah 0,7837 atau 78,37 persen, besarnya koefisen jalur customer value (X2) terhadap kepuasan mahasiswa (Y) adalah 0,3649 atau 36,49 persen.Serta besarnya koefisien jalur variable luar (Pye) dapat dilihat pada Grafik sebagai berikut : 


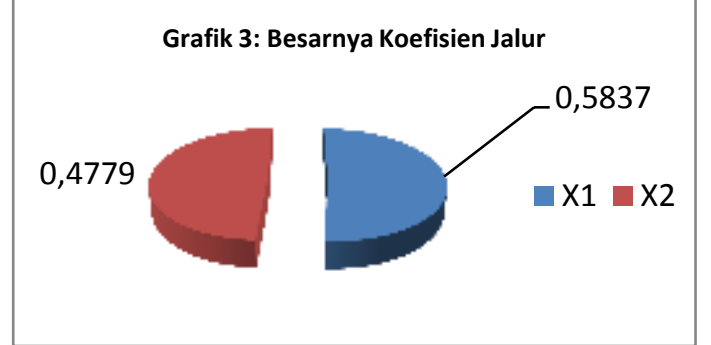

Sumber: dari data olahan tahun 2017

Interpretasi hipotesis penelitian yaitu pengaruh kualitas costumer value terhadapkepuasan mahasiswa.Hipotesis ketiga menyatakan bauran pemasaran jasa dan costumer value berpengaruh secara simultan terhadap kepuasan mahasiswa. Artinya kepuasan mahasiswa(Y) ditentukan oleh bauran pemasaran jasa $\left(\mathrm{X}_{1}\right)$ dan custumer value $\left(\mathrm{X}_{2}\right)$.

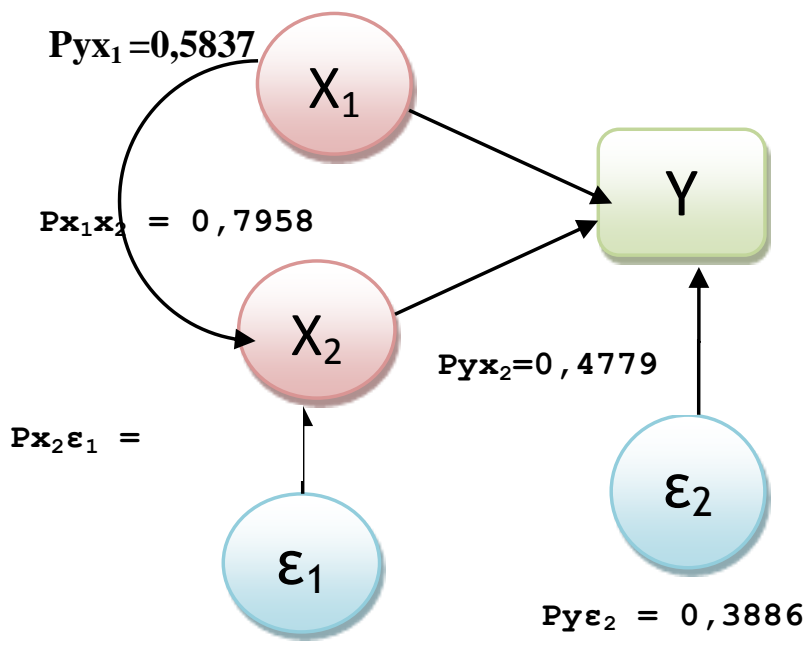

Gambar 2

Interpretasi pengaruh $\mathrm{X} 1, \mathrm{X} 2$ dan $\mathrm{Y}$

\section{Kesimpulan}

Berdasarkan dari data deskriptif,hasil analisis data dan pembahasan hasil penelitian yang telah dijabarkan sebelumnya,maka dapat disimpulkan sebagai berikut:

1. Tanggapan mahasiswa terhadap bauran pemasaran jasa. Bauran pemasaran jasa terutama yang berkaitan kepuasan mahasiswa terdiri dari tujuh subvariabel yaitu produk (product), harga (price), distribusi (place), promosi (promotion), orang (people), bukti langsung (physical evidence) dan proses (process)yang secara umum memiliki tanggapan yang relatif baik.

2. Customer value yang diterima mahasiswa terhadap Program Studi Manajemen Fakultas Ekonomi UMRAH sebagian besar menilai tinggi.

3. (a) Bauran Pemasaran Jasa baik secara langsung maupun tidak langsung berpengaruh positif terhadap kepuasan mahasiswa Program Studi Manajemen Fakultas Ekonomi UMRAH.Hal ini menunjukan bahwa bauran pemasaran jasa dapat menstimulir peningkatan kepuasan mahasiswa.

(b) Costumer value baik secara langsung maupun tidak langsung berpengaruh positif terhadap hasil penjualan pada perusahaan karet alam sumatera barat. Hal ini menujukkan bahwa customer value dapat menstimulir peningkatan hasil penjualan karet alam.

(c) Bauran Pemasaran Jasadan costumer value yang diterima mahasiswa secara simultan yang berpengaruh erat terhadap kepuasan mahasiswa Program Studi Manajemen Fakultas Ekonomi UMRAH. Hal ini berarti Bauran Pemasaran Jasadan customer value secara bersama-sama berperan dalam upaya untuk meningkatkan kepuasan mahasiswa Program Studi Manajemen Fakultas Ekonomi UMRAH.

\section{Saran}

1. Bauran Pemasaran Jasaperlu terus dipertahankan yang meliputi dimensi produk (product), harga (price), distribusi (place), promosi (promotion), orang (people), bukti langsung (physical evidence) dan proses (process)sehingga mahasiswa merasa, pengawasan pada kinerja 
2. Bauran Pemasaran Jasa perlu mendapat perhatian yang lebih. Walaupun fakultas dan Prodi dalam keadaan keterbatasan namun tidak menutup kemungkinan memberikan pelayanan yang baik dan memberikan nilai yang lebih yang dapat dirasakan oleh mahasiswa, mengingat pengaruhnya besar dalam penelitian ini.Hal ini juga penanganan terhadap konsistensi bauran pemasaran jasa perlu mendapat perhatian serius mengingat fakta secara empiris diketahui bahwa perihal ini merupakan faktor penting yang dipertimbangkan oleh calon mahasiswa baik dari dalam derah sendiri maupun daerah lain.

3. Untuk meningkatkan kepuasan mahasiswa melalui penciptaan customer value yang tinggi bagi mahasiswa, secara umum customer benefit yang diterima mahasiswa yang dirasakan tinggi dibandingkan dengan customer cost yang telah dikeluarkan namun tidak menutup kemungkinan bagi Fakultas dan Prodi Manajemen melakukan pembenahan dan perbaikan dalam beberapa hal dengan demikian mahasiswa dapat meningkatkan efisiensi biaya, waktu tenaga dan psikis yang dikorbankan untuk memperoleh pendidikan yang baik. 


\section{Daftar Pustaka}

Donald R. Cooper \& Pamela S. Schinder, 2006, Business Research Methods", 9 th edition, McGraw-Hill International Edition

Freddy Rangkuti, 2002, Measuring Customer Satisfaction: Teknik Mengukur dan Strategi Meningkatkan Kepuasan Pelanggan dan Analisis Kasus PLN.JP. PT. Gramedia Pustaka Utama, Jakarta

Jasfar, Farida, 2005, Manajemen Jasa Pendekatan terpadu. Ghalia Indonesia, Bogor

Kotler, Philip, 2005, Marketing Management; international Edition, Prentice Hall. Inc, New Jersey

Lovelock, Christopher, $\mathrm{H}$ and Wright Lauren, 2002, Priciples of service Marketing Management, USA: Prentice-Hall

Lupiyoadi, Rambat dan A. Hamdani, 2011, Manajemen Pemasaran Jasa, edisi 2, Jakarta:Salemba Empat.

Malhotra, N.K, 2004, Marketing Research; An Applied Oreintation, New Jersey: Pearson Education

Parasuraman, A et all 1996, "SERQUAL: A Multyple-Item Scale for Measuring Consumer Perception of Srvice Quality". Journal of Reailing 64 (1); 12 40

Payne, Andrian, 2001, The Essence Of Service Marketing. Diterjemahkan oleh:
Fandy Tjiptono, edisi Pertama, Penerbit Andi, Yokyakarta.

Selnes , 1993:30) dan Nguyen \& Lebblanc (2001), jurnal ilmu Manajemen

Singarimbun, M., \& Effendi, S, 1989. Metode Penelitian Survei, Jakarta: LP3ES

Stanton, William, J, 2004, Fundamental of Marketing, 11th ed, McGraw Hill, Norh America

Sucherly, 2001, Kinerja Startegi Bauran Pemasaran Jasa SLI 008, Pengaruhnya terhadap Nilai Jasa dan Loyalitas Pelanggan PT. Satelit Palapa Indonesia. Makalah yang disajikan pada temu ilmiah Sewindhu Program Magister Manajemen Universitas Padjajaran.

Sugiyono, 2000, Statistika untuk Penelitian, CV. Alfabeta, Bandung

Umar, Husein, 2010, Metode Penelitian Untuk Skripsi dan Tesis Bisnis, Jakarta:Rajagrafindo Persada.

Widjaya Amin, 2005. Tanya jawab : Perilaku Konsumen dan Pemasaran Strategi, Gramedia Pustaka Utama, Jakarta.

Yamit, Zulian, 2001. Manajemen Kualitas Produk dan Jasa. Ekonisia, Yokyakarta

Zeithaml, V.A.,Berry, L.L., \& Parasuraman,A. 1996, The Behavioral Consequences of Service Quality, Journal of marketing, 60 